\title{
RECOVERY OF VENTILATORY RESPONSE TO CARBON DIOXIDE AFTER THIOPENTONE, MORPHINE AND FENTANYL IN MAN
}

\author{
J.R.A. Rigg AND C.H. GoLdsmith*
}

Following GeNeral ANAESTHesia, the return of spontaneous ventilation may be delayed. Frequently, this can be attributed to a relative drug overdose, or an unanticipated drug sensitivity or reaction; however, there are occasions when such a delay cannot be so explained. It is possible that differences in the operation of respiratory control mechanisms among patients may account for variation in the rate of recovery of spontaneous ventilation after anaesthesia.

The ventilatory response to an increasing concentration of inspired carbon dioxide is recognized as a sensitive index of respiratory control and is known to vary widely among normal people. ${ }^{1,2}$ Anaesthetics and other central nervous depressant drugs decrease the response in a quantitative dose-related manner. ${ }^{3-7}$ Furthermore, it has been postulated that low respiratory sensitivity to carbon dioxide may render people more susceptible to ventilatory depressant effects of anaesthetic drugs, ${ }^{8}$ but, to our knowledge, this idea has not been tested formally. If this suggestion is true, then it supports the hypothesis that differences in recovery of control of breathing may have a physiological (in addition to a pharmacological) basis. In this study, we measured ventilatory response to carbon dioxide after infusions of thiopentone, fentanyl, morphine and saline in healthy men, to shed light on these problems.

\section{METHODS}

Principle: Ventilation $\left(\dot{\mathrm{V}}_{\mathrm{I}}\right)$ and end tidal $\mathrm{CO}_{2}\left(\operatorname{PET}_{\mathrm{CO}_{2}}\right)$ were measured before, during and intermittently after infusions of thiopentone, fentanyl, morphine and saline (control) in healthy men. Ventilatory response to carbon dioxide was measured before and at half, one, two and four hours after each infusion.

Subjects: Eight healthy male volunteers, none of whom had previously participated in drug experiments, were studied. None gave a history of cardiovascular, respiratory or neurological disease. All gave informed consent to the experiments; the subjects understood all the procedures involved but were not aware of the rationale of the study. Their physical characteristics are given in Table I.

Equipment: Ventilation was measured with a Parkinson-Cowan CD4 dry gas meter, precise to \pm 2 per cent. Carbon dioxide was measured with a Godart infra red analyzer, with a response time of 0.1 second, and a precision of \pm 0.1 per cent over the range of $0-10$ per cent. The analyzer was calibrated with three gas mixtures of carbon dioxide in 40 per cent oxygen and balance nitrogen, previously

'Departments of Anaesthesia and Clinical Epidemiology and Biostatistics, McMaster University, Hamilton, Ontario L8S 4J9.

Address for reprints: Dr. J.R.A. Rigg, Department of Anaesthesia, Room 4V34, McMaster University Medical Centre, 1200 Main Street West, Hamilton, Ontario L8S 4J9, Canada. 
TABLE I

Physical Characteristics of Subjects Studied

\begin{tabular}{|c|c|c|c|c|c|c|c|c|}
\hline \multirow[b]{2}{*}{ Subject } & \multirow[b]{2}{*}{$\begin{array}{l}\text { Age } \\
(\mathrm{yr})\end{array}$} & \multirow[b]{2}{*}{$\begin{array}{c}\text { Weight } \\
(\mathrm{kg})\end{array}$} & \multirow[b]{2}{*}{$\begin{array}{c}\text { Height } \\
(\mathrm{cm})\end{array}$} & \multirow[b]{2}{*}{$\begin{array}{l}\text { V.C. } \\
\text { (1) }\end{array}$} & \multicolumn{4}{|c|}{ Doses } \\
\hline & & & & & $\begin{array}{l}\text { Thiopentone } \\
(\mathrm{mgm} / \mathrm{kg})\end{array}$ & $\begin{array}{l}\text { Morphine } \\
(\mathrm{mgm} / \mathrm{kg})\end{array}$ & $\begin{array}{l}\text { Fentany } \\
(\mu \mathrm{gm} / \mathrm{kg}\end{array}$ & \\
\hline $\begin{array}{l}1 \\
2 \\
3 \\
4 \\
5 \\
6 \\
7 \\
8\end{array}$ & $\begin{array}{l}36 \\
41 \\
30 \\
31 \\
28 \\
28 \\
31 \\
33\end{array}$ & $\begin{array}{l}82.2 \\
73.5 \\
89.3 \\
77.5 \\
81.9 \\
75.0 \\
96.0 \\
73.4\end{array}$ & $\begin{array}{l}182.0 \\
182.9 \\
181.4 \\
186.0 \\
178.5 \\
180.3 \\
186.6 \\
176.5\end{array}$ & $\begin{array}{l}4.7 \\
4.76 \\
6.5 \\
5.4 \\
5.3 \\
5.7 \\
6.0 \\
6.2\end{array}$ & $\begin{array}{l}3.65 \\
5.74 \\
5.89 \\
3.41 \\
5.80 \\
6.00 \\
6.26 \\
6.00\end{array}$ & $\begin{array}{c}0.113 \\
0.114 \\
0.113 \\
0.118 \\
= \\
=\end{array}$ & $\begin{array}{l}1.25 \\
1.28 \\
1.11 \\
- \\
1.11 \\
2.00 \\
2.00 \\
2.00\end{array}$ & $\begin{array}{l}3.00 \\
4.00\end{array}$ \\
\hline
\end{tabular}

analyzed in a Lloyd-Haldane apparatus. A continuous record of end tidal carbon dioxide and ventilation was obtained with an Astromed pen recorder. Ventilatory response to carbon dioxide $\left(\Delta \dot{\mathrm{V}}_{\mathrm{I}} / \Delta \mathrm{P}_{\mathrm{CO}_{2}}\right)$ was measured by the method of Read, ${ }^{9}$ using criteria of validity described previously. ${ }^{10}$ During rebreathing, gas sampled by the analyzer was returned to the bag. The resistance of the rebreathing circuit was $1.0 \mathrm{~cm} \mathrm{H} \mathrm{H}_{2} \mathrm{O} / \mathrm{l} \mathrm{sec}$. at a flow rate of $4 \mathrm{l} / \mathrm{sec}$. The experimental circuit is shown in Figure 1.

Thiopentone, morphine and fentanyl were selected for study for practical reasons. First, their administration could be more precisely controlled than inhaled drugs. Secondly, thiopentone and morphine were chosen because they are widely used traditional representatives of the barbiturate and narcotic drug groups. Fentanyl was studied because it is widely used to maintain general anaesthesia and is known to be a potent respiratory depressant. Doses given were within clinically used ranges, so that clinical inferences might be drawn from the results (Table I). Each drug was infused as a dilute solution, varying between 50 and 80 $\mathrm{ml}$ and given at rates between 2 and $4 \mathrm{ml} / \mathrm{min}$. In control experiments, $50 \mathrm{ml}$ of saline was given. During all experiments, the electrocardiograph lead II was monitored with a Hewlett Packard heart pulse monitor 7807C and displayed on a Hewlett Packard oscilloscope 7803B. Blood pressure was measured with a sphygmomanometer.

Procedure: All experiments were conducted in a quiet, darkened room, to reduce unnecessary distractions. Each subject had fasted for at least four hours before an experiment and had emptied his bladder immediately before entering the laboratory. An intravenous infusion of normal saline was established in the left arm and maintained for the duration of the experiment at $150-200 \mathrm{ml} / \mathrm{hr}$. The drug solution was infused through a second intravenous cannula in the right arm. All displays of physiological variables were screened from the subject and care was taken to ensure constant ambient temperature.

Two series of experiments were conducted. In the first, four subjects were studied in separate experiments with thiopentone and three with fentanyl and morphine. Two thiopentone infusions were terminated prematurely at nine minutes ( subject 1 ) and eight minutes ( subject 4) because of partial upper airway 


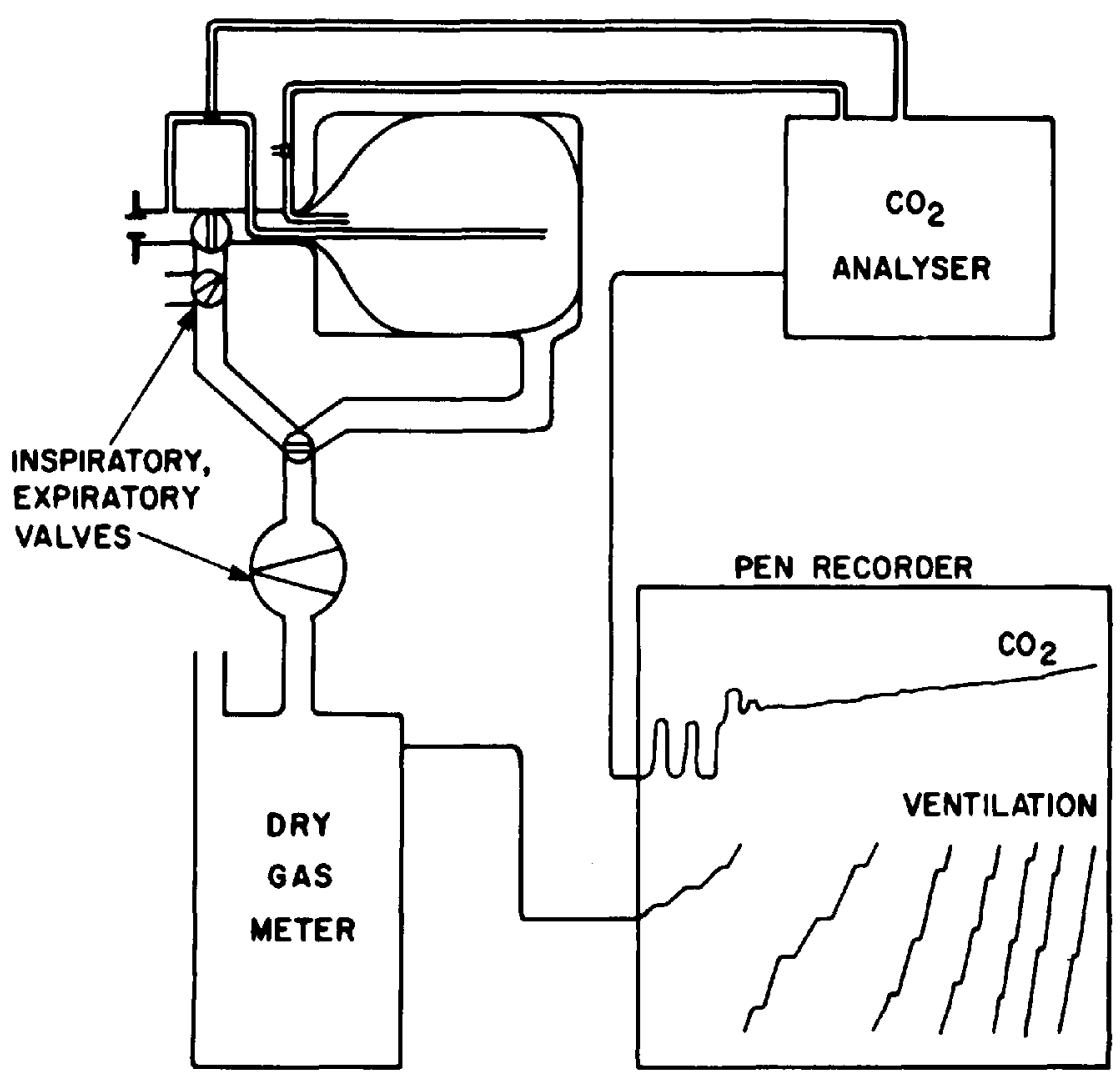

Figure 1. Diagram of rebreathing circuit.

obstruction. The obstruction was transient and rapidly resolved within two minutes of stopping the infusion. These two experiments were conducted and completed with an otherwise identical protocol; no airway obstruction occurred during any recovery measurement of $\Delta \dot{V}_{1} / \Delta \mathrm{P}_{\text {con. }}$. The doses prepared for infusion were: thiopentone, $6 \mathrm{mg} / \mathrm{kg}$; morphine, $0.12 \mathrm{mg} / \mathrm{kg}$, and fentanyl, $1.3 \mu \mathrm{g} / \mathrm{kg}$. The small differences between these and the actual doses (Table I) were due to varying differences in dead space between the injection syringe (mounted in a Harvard infusion pump, No. 45034) and the intravenous cannula. In the second series of experiments, three additional subjects were studied, with fentanyl, thiopentone and saline; higher doses of fentanyl were given (Table I). The drugs in these experiments were also given by slow infusion, but by manual injection, to achieve greater dose precision.

Control measurements of $\dot{\mathrm{V}}_{\mathrm{I}}$ and $\mathrm{PET}_{\mathrm{CO}_{2}}$ were obtained before the infusion was started. In all carbon dioxide response tests, the strict criteria necessary for 'open loop' conditions with respect to the increasing carbon dioxide stimulus were observed. ${ }^{10}$ Peripheral venous blood was sampled during the control period and at $10,20,30,45,60,120$ and 240 minutes after the start of drug infusion, for determination of plasma drug concentrations. All control measurements were obtained within one hour of starting of an experiment; and resting ventilation then resumed 
until a stable pattern of breathing was established, when the infusion was begun. The ventilatory response to carbon dioxide was measured at half, one, two and four hours after the infusion, except in three thiopentone experiments in which subjects were too drowsy to co-operate with the half-hour measurement. Each experiment was performed on a separate day, and no subject underwent two experiments at intervals of less than five days. Only J.R.A. Rigg was aware of the identity of the drug being infused.

Drug Analysis: Plasma thiopentone was measured by a spectrofluorometric method. ${ }^{11}$

Data Analysis: The slope of the ventilatory response to carbon dioxide was calculated by the method of Read ${ }^{9,10}$ and tidal volume $\left(\Delta \mathrm{V}_{\mathrm{T}} / \Delta \mathrm{P}_{\mathrm{CO}_{2}}\right)$ and frequency response slopes $\left(\Delta \mathrm{f} / \Delta \mathrm{P}_{\mathrm{CO}_{2}}\right)$ were calculated similarly. To assess displacement of response curve slopes by the drugs, $\dot{\mathrm{V}}_{\mathrm{I}}$ at $\mathrm{P}_{\mathrm{CO}_{2}}=58$ and $70 \mathrm{mmHg}\left(\dot{\mathrm{V}}_{\mathrm{I}_{58}}\right.$ and $\left.\dot{\mathrm{V}}_{\mathrm{I}_{70}}\right)$ were computed by substitution in each regression equation. The significance of drug induced changes was determined with paired "t" tests.

\section{Results}

During all drug infusions, there was a progressive fall of $\dot{V}_{\mathrm{I}}$, followed by a progressive rise of $\mathrm{PET}_{\mathrm{CO}_{2}}$. The maximum decrease of $\dot{\mathrm{V}}_{\mathrm{I}}$ occurred from 12 to 20 minutes after the start of infusions and preceded the maximum change of $\mathrm{PET}_{\mathrm{CO}_{2}}$ by two to four minutes. Depression of ventilation following thiopentone was due to a reduction of $\mathrm{V}_{\mathrm{T}}$ and this was associated with a partially-compensating increase of breathing frequency. In contrast, following both morphine and fentanyl, depression of $\dot{V}_{I}$ was due to a reduction of $f, V_{T}$ being relatively well maintained (Figure 2). During saline infusions, all variables changed little and these changes were random in direction.

The ventilatory response to carbon dioxide was profoundly reduced one half hour after each drug (Figure 3), compared to the observation during air breathing immediately preceding rebreathing in that $\dot{\mathrm{V}}_{\mathrm{I}}, \mathrm{V}_{\mathrm{T}}, \mathrm{f}$ and $\mathrm{PET}_{\mathrm{CO}_{2}}$ had returned to within 10 per cent of control. Mean $A \dot{V}_{\mathrm{l}} / \Delta \mathrm{P}_{\mathrm{CO}_{2}}$ increased progressively at one, two and four hours, returning to near control after thiopentone at the end of that period. In contrast it remained less than 80 per cent of control four hours after morphine and fentanyl. At one half hour, depression of $\Delta \dot{\mathrm{V}}_{\mathrm{I}} / \Delta \mathrm{P}_{\mathrm{CO}_{2}}$ was achieved by a near proportional reduction of tidal volume $\left(\Delta \dot{\mathrm{V}}_{\mathrm{T}} / \Delta \mathrm{P}_{\mathrm{CO}_{2}}\right)$ and frequency responses to carbon dioxide $\left(\Delta \mathrm{f} / \Delta \mathrm{P}_{\mathrm{CO}_{2}}\right.$ ) (Figure 3 ). However, $\Delta \mathrm{V}_{\mathrm{T}} / \Delta \mathrm{P}_{\mathrm{CO}_{2}}$ recovered quickly and was near control at 1 hour, residual depression of $\Delta \dot{\mathrm{V}}_{\mathrm{I}} / \Delta \mathrm{P}_{\mathrm{CO}_{2}}$ at one, two and four hours being due largely to depression of $\Delta f / \Delta \mathrm{P}_{\mathrm{CO}_{2}}$ (Figure 3).

Following thiopentone, there was no significant change of $\dot{\mathrm{V}}_{\mathrm{I}_{58}}$. In contrast, there was a highly significant fall of $\dot{\mathrm{V}}_{\mathrm{I}_{58}}$ one half hour after fentanyl $(\mathrm{p}<0.01)$, with progressive return towards control at one, two and four hours. Changes following morphine were similar in direction and magnitude but were not statistically significant given the small number of subjects studied. Changes of $\dot{V}_{1_{70}}$ were more substantial one half hour after each drug and were significant after both fentanyl $(\mathrm{p}<0.01)$ and morphine $(\mathrm{p}<0.05)$. One hour after thiopentone, $\dot{\mathrm{V}}_{\mathrm{I}_{70}}$ had returned to near normal but remained significantly lower and for a longer period 


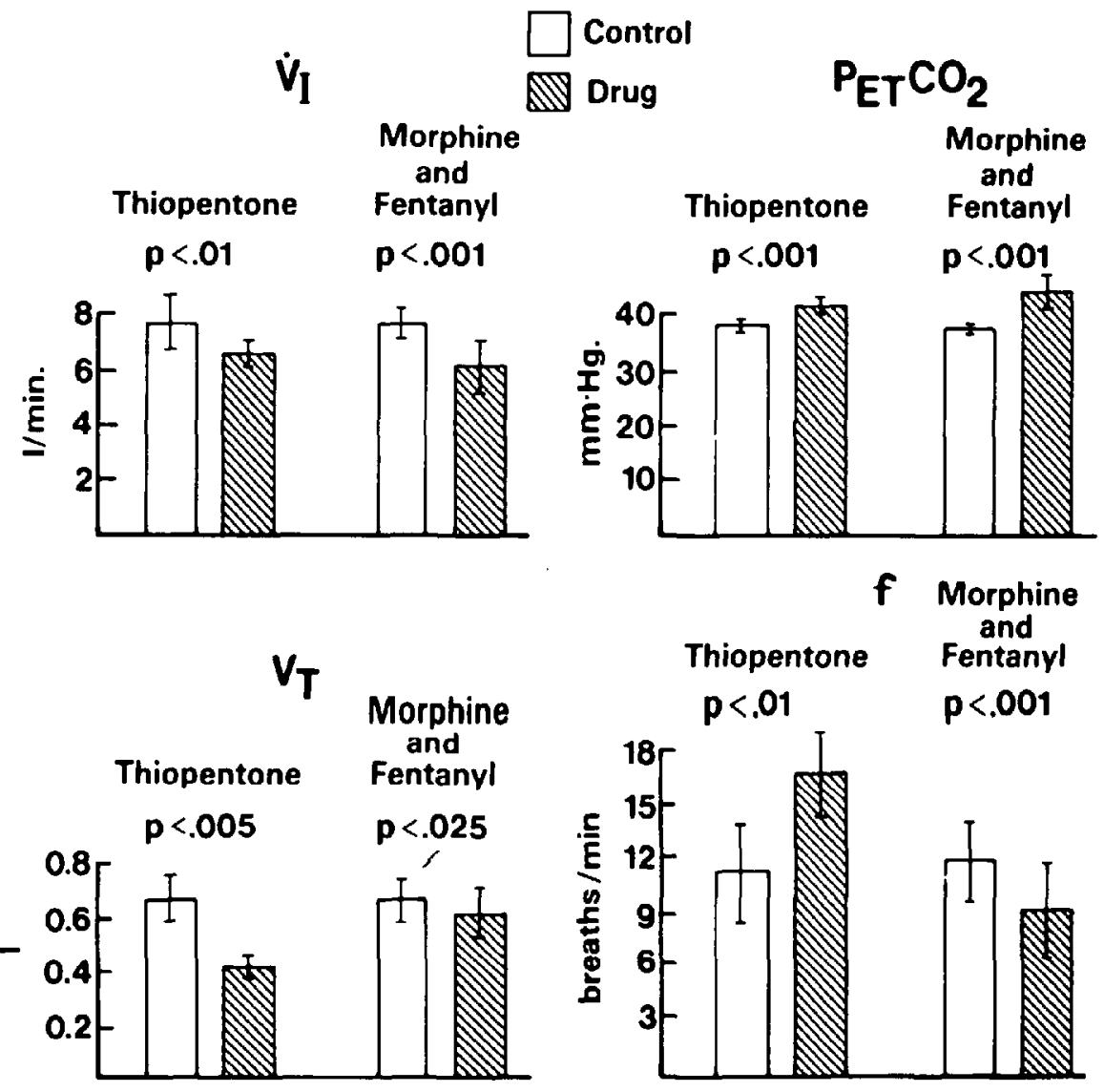

FIGuhe 2. Ventilation $\left(\dot{V}_{\mathrm{I}}\right)$, end tidal $\mathrm{CO}_{2}\left(\operatorname{PETco}_{2}\right)$, tidal volume $\left(\mathrm{V}_{\mathrm{T}}\right)$ and frequency of breathing (f) breathing air before infusions of thiopentone, morphine and fentanyl and at the time of maximum change of each variable during respective drug infusions. All values are means $\pm S D$.

after both fentanyl and morphine. Subjects were conscious and co-operative during recovery measurements and were judged by traditional clinical criteria to have recovered from the effects of the drugs.

Differences between high and low responding subjects were assessed by plotting control $\Delta \dot{V}_{1} / \Delta \mathrm{P}_{\mathrm{CO}_{2}}, \Delta \mathrm{V}_{\mathrm{T}} / \Delta \mathrm{P}_{\mathrm{CO}}$ and $\Delta \mathrm{f} / \Delta \mathrm{P}_{\mathrm{CO}_{2}}$ against values obtained one half and 1 hour after the drugs (Figure 4 ). These plots show considerable scatter, indicating that control response slopes had no detectable systematic relationship to the drug induced changes.

Thiopentone concentrations in peripheral venous blood (means \pm SD) at half, one, two and four hours were $6.2 \pm 0.48,5.4 \pm 0.38,3.6 \pm 0.45$ and $1.9 \pm 0.54$ $\mu \mathrm{gm} / \mathrm{ml}$ respectively (Figure 5). Morphine and fentanyl concentrations were not measured. The relationship of mean values of $\Delta \dot{V}_{1} / \Delta \mathrm{P}_{\mathrm{CO}_{2}}, \Delta \mathrm{V}_{\mathrm{T}} / \Delta \mathrm{P}_{\mathrm{CO}_{2}}$ and $\Delta \mathrm{f} / \Delta \mathrm{P}_{\mathrm{CO}}$ respectively to mean plasma thiopentone concentrations are shown in Figure 6. In individual subjects, however, no relationship was detected between plasma thiopentone concentration and change of $\Delta \dot{\mathrm{V}}_{\mathrm{I}} / \Delta \mathrm{P}_{\mathrm{CO}_{2}}$ expressed as a per cent of control. 
THIOPENTONE DORPHINE D FENTANYL
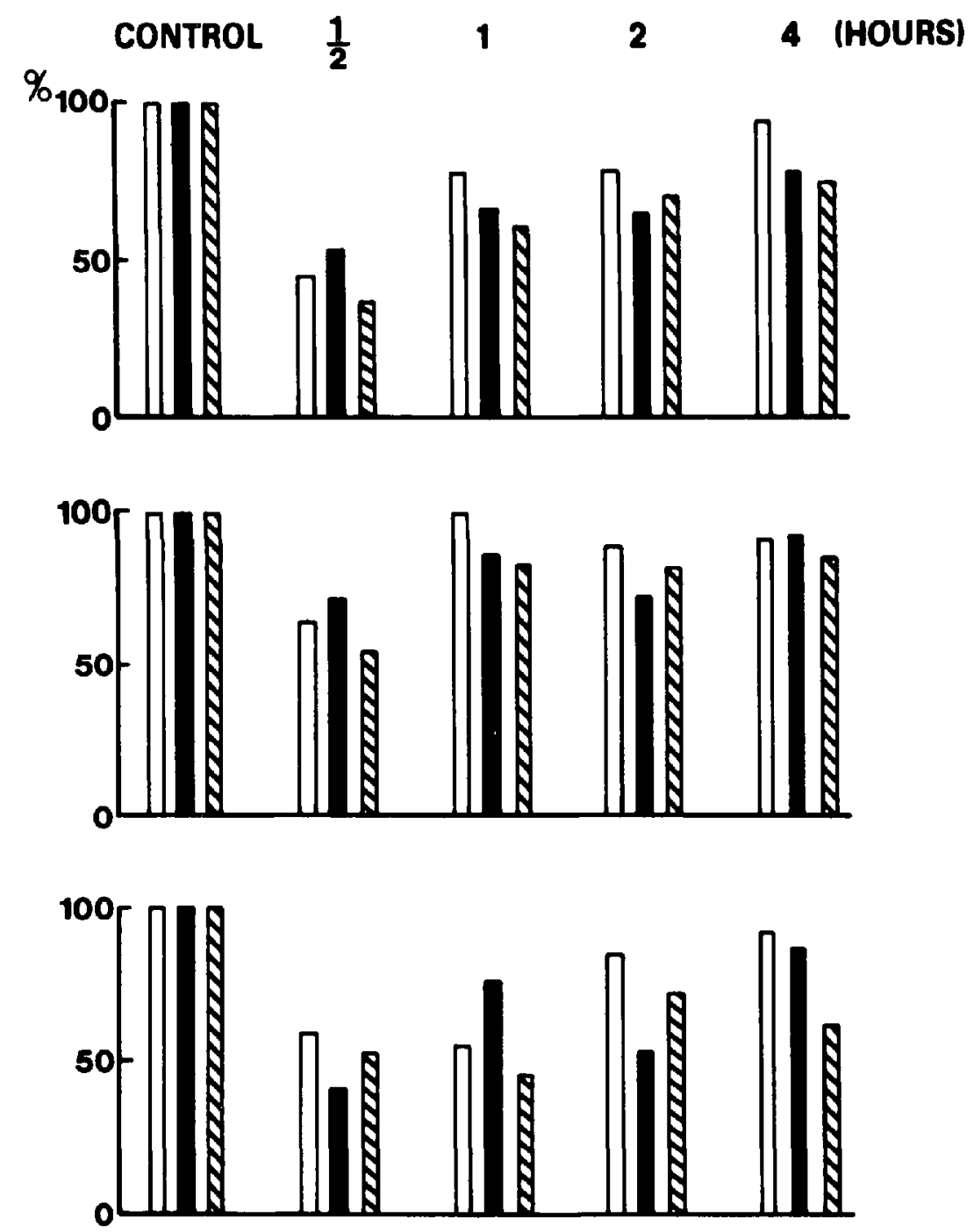

Figure 3. Ventilatory $\left(\Delta \dot{\mathrm{V}}_{\mathrm{I}} / \Delta \mathrm{P}_{\mathrm{co}}\right)$ (upper panel), tidal volume $\left(\mathrm{V} \Delta_{\mathrm{T}} / \Delta \mathrm{P}_{\mathrm{C}} \mathrm{o}_{\mathrm{g}}\right)$ middle panel), and frequency ( $\Delta \mathrm{f} / \Delta \mathrm{P}_{\mathrm{CO}_{2}}$ ) (lower panel) responses to carbon dioxide before and half, one, two and four hours after thiopentone, morphine and fentanyl. All values are means, expressed as per cent of control."

\section{Discussion}

A profound depression of response curve slopes was found one half hour after drug infusion, in contrast to the observations that during air breathing immediately before rebreathing, $\dot{\mathrm{V}}_{\mathrm{I}}$ and $\mathrm{PET}_{\mathrm{CO}_{2}}$ were within 10 per cent of control and that subjects were conscious, co-operative and apparently had fully recovered. These results suggest that $\Delta \dot{\mathrm{V}}_{\mathrm{I}} / \Delta \mathrm{P}_{\mathrm{CO}_{2}}$ is a sensitive indicator of central nervous activity,

-Detailed tables of observations may be obtained from the senior author. 

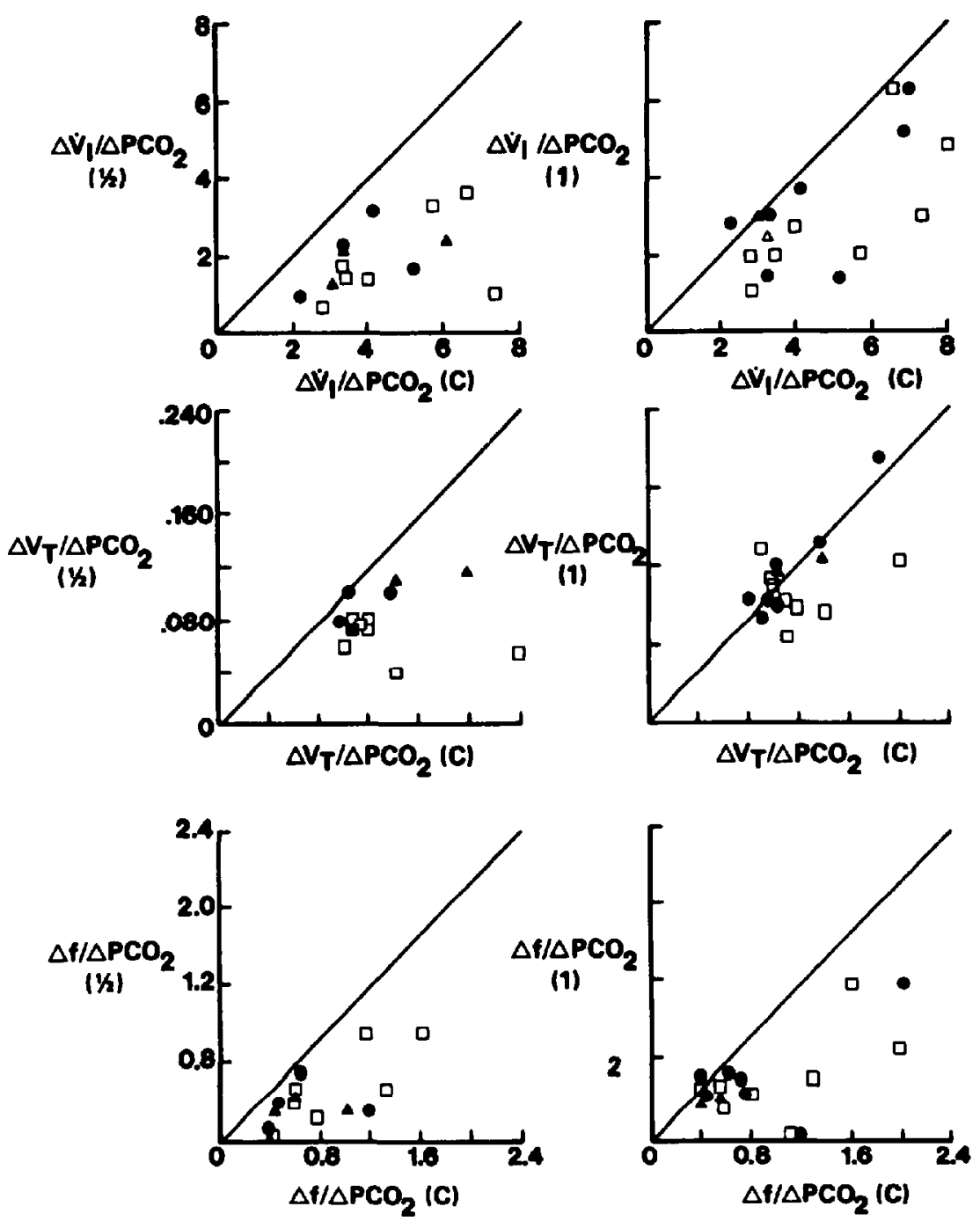

Figure 4. Control carbon dioxide reponse curve slopes plotted against slopes at half and one hour after thiopentone, morphine and fentanyl. Upper panel $-\Delta \dot{\mathrm{V}}_{\mathrm{I}} / \Delta \mathrm{P}_{\mathrm{co}_{3}}$, middle panel $\Delta \mathrm{V}_{\mathrm{T}} / \Delta \mathrm{P}_{\mathrm{CO}_{2}}$ and lower panel $-\Delta \mathrm{f} / \Delta \mathrm{P}_{\mathrm{CO}_{2}} \cdot{ }^{*}$

although in individual subjects the drug-induced changes were quantitatively unpredictable both in their time course and in their relationship to control responses (Figure 4).

The latter finding does not support the hypothesis that low responders are more susceptible to the ventilatory depressant effects of anaesthetic drugs than high responders, and contrasts with evidence that patients with low responsiveness to carbon dioxide, asthma or chronic bronchitis are more likely to develop hypercapnia and acute exacerbation of their disease than are high-responding patients. ${ }^{2,12}$ However, we do not conclude that the hypothesis has been disproved at

-Detailed tables of observations may be obtained from the senior author. 


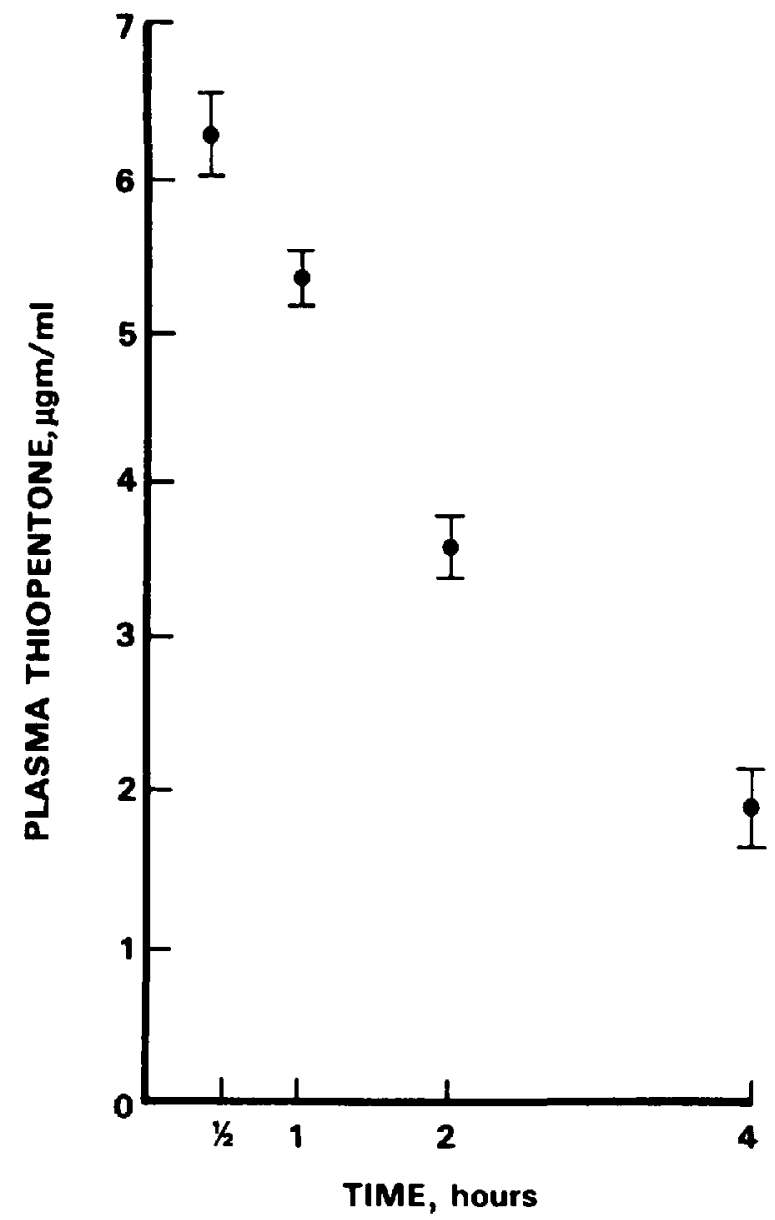

FIGURE 5. Mean plasma thiopentone concentrations plotted against time of sampling after drug administration. ${ }^{*}$

present because of the considerable variation in $\Delta \dot{V}_{I} / \Delta \mathrm{P}_{\mathrm{CO}_{2}}$ from one person to another in both control and drug experiments. This variability contrasts with the high reproducibility obtained in previous experiments in this laboratory, experiments in which similar strict criteria for attainment of open loop conditions during rebreathing were met. ${ }^{10}$ In both these series of experiments, the rates of change of carbon dioxide tension during rebreathing $(\mathrm{dp} / \mathrm{dt})$ were reproducible and of comparable magnitude, indicating that the hypercapnic drive to breathing was comparable in the two studies. The variation found in the present study may be the result of uncontrolled factors, other than carbon dioxide, which affect the nervous system. ${ }^{13}$ It is possible that non-steady state rebreathing enhances variation in responsiveness caused by such nervous factors; unfortunately the steady state carbon dioxide response technique is not suitable for drug studies since it is

- Detailed tables of observations may be obtained from the senior author. 


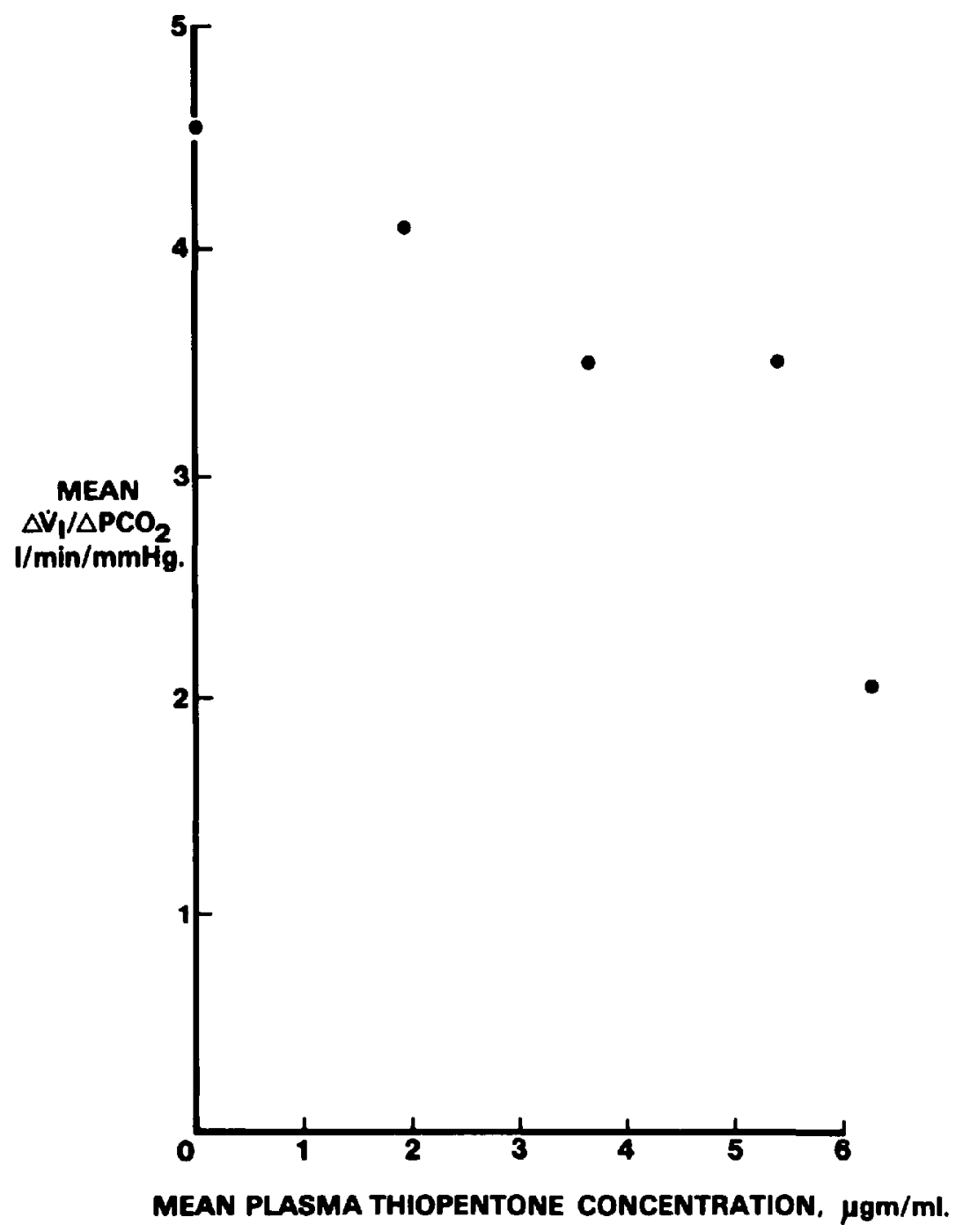

Figuhe 6. Mean plasma thiopentone concentration plotted against mean $\Delta \dot{\mathrm{V}}_{1} / \Delta \mathrm{P}_{\mathrm{C}_{\mathrm{g}}}$, half, one, two and four hours after thiopentone.

not possible to achieve a pharmacological steady state for the time needed to obtain a carbon dioxide response. ${ }^{14}$

The effect of narcotics and other central depressant drugs on the ventilatory response to carbon dioxide have been studied extensively. ${ }^{3,5,15,16}$ Bellville and Seed concluded that opiates caused a parallel shift in the response curve but little alteration in slope, a conclusion that differs from the present findings. ${ }^{3}$ The differences are probably attributable to the different methods employed; steady state or nonopen-loop rebreathing techniques were used in the early studies. Bülow studied changes in carbon dioxide responsiveness during physiological sleep and he also found that the predominant change was in the position of the response curve, with

-Detailed tables of observations may be obtained from the senior author. 
only slight and variable changes in slope. ${ }^{17}$ This difference, also, may be due to different methodology; however, Bülow's conclusion that carbon dioxide response changes with sleep are mediated by non-chemical nervous mechanisms is consistent with our interpretation of the present findings.

The fall of $\Delta \dot{\mathrm{V}}_{\mathrm{r}} / \Delta \mathrm{P}_{\mathrm{CO}_{2}}$ one half hour after drugs was due to a fall of both $\Delta \mathrm{V}_{\mathrm{T}} / \Delta \mathrm{P}_{\mathrm{CO}_{2}}$ and $\Delta \mathrm{f} / \Delta \mathrm{P}_{\mathrm{CO}_{2}}$. However, $\Delta \mathrm{f} / \Delta \mathrm{P}_{\mathrm{CO}_{2}}$ was generally more depressed than $\Delta V_{\mathrm{T}} / \Delta \mathrm{P}_{\mathrm{CO}_{2}}$ and tended to remain below control values to a greater degree in the one-, two-, and four-hour measurements. This finding suggests that these drugs have their major impact on neural mechanisms governing the frequency of breathing rather than on the chemical drive thought to be the primary control of tidal volume. ${ }^{18,19}$

Drug-induced changes of ventilatory responses varied such that no differences were apparent between high- and low-dose thiopentone and fentanyl experiments. In a comparative study of narcotic drugs, Jennett, Barker and Forrest found a similar variation. ${ }^{20}$ In both their studies and ours the pharmacological states induced may be associated with increased excitability of the nervous system, corresponding with the excitatory phenomena that occur during a light anaesthesia ${ }^{21,22}$; this could conceivably account for the observed fluctuations of $\Delta \dot{V}_{1} / \Delta \mathrm{P}_{\mathrm{CO}_{2}}$. However, it does not account for increased $\Delta \dot{\mathrm{V}}_{\mathrm{I}} / \Delta \mathrm{P}_{\mathrm{rO}_{2}}$ in some of the present saline experiments. Anxiety may contribute to this effect, since anxiety is known to elevate circulating catecholamines, and catecholamines have been shown to increase $\Delta \dot{\mathrm{V}}_{\mathrm{I}} / \Delta \mathrm{P}_{\mathrm{CO}_{2}}{ }^{23}$ Anxiety was not assessed formally in this study, but subjects with the largest increases in slopes following saline appeared to be more anxious.

The foregoing arguments support the concept that variations in clinical recovery and ventilatory response to carbon dioxide during recovery from anaesthesia may have a physiological in addition to a pharmacological basis. Analyses of plasma thiopentone concentrations in the present study provide further support for this view, as the variation of drug concentration at half, one, two, and four hours among subjects was considerably less than that of corresponding $\Delta \dot{V}_{1} / \Delta P_{\mathrm{CO}_{2}}$ measurements (Figure 5). There are two possible interpretations of this finding. First, plasma concentration may not bear a consistent relationship to brain concentration during recovery in different individuals and therefore may not quantitatively reflect drug activity in the respiratory control system. Alternatively, and this seems a more likely explanation, non-drug related factors such as those discussed above, may be causing variable responsiveness and may be overriding the residual pharmacological effect in subjects who were apparently recovered when assessed by conventional clinical criteria.

\section{SUMMARY}

Ventilatory responses to $\mathrm{CO}_{2}\left(\Delta \dot{\mathrm{V}}_{\mathrm{I}} / \Delta \mathrm{P}_{\mathrm{CO}_{2}}\right)$ were measured half, one, two, and four hours after infusions of thiopentone, morphine, fentanyl and saline in healthy men in order to test the idea that variation in clinical recovery and control of breathing after anaesthetic drugs are associated with interindividual differences in control measurements of $\Delta \dot{\mathrm{V}}_{\mathrm{I}} / \Delta \mathrm{P}_{\mathrm{CO}_{2}}$. Ventilatory response to $\mathrm{CO}_{2}$ was profoundly 
reduced one half hour after each drug, in contrast to the observation during air breathing that ventilation and end tidal $\mathrm{P}_{\mathrm{CO}_{2}}$ had returned to within 10 per cent of control. Mean $\Delta \dot{\mathrm{V}}_{\mathrm{I}} / \Delta \mathrm{P}_{\mathrm{Co}_{2}}$ increased progressively at one, two, and four hours, returning to near control after thiopentone, but remaining less than 80 per cent of control four hours after morphine and fentanyl. From the regression equations of each ventilatory response, ventilation at $\mathrm{P}_{\mathrm{CO}_{2}}$ of 58 and $70 \mathrm{mmHg}\left(\dot{\mathrm{V}}_{\mathrm{I}_{58}}\right.$ and $\left.\dot{\mathrm{V}}_{\mathrm{I}_{70}}\right)$ were computed to estimate displacement of the response curves by the drugs. Following thiopentone there was no significant change of $\dot{\mathrm{V}}_{\mathrm{I}_{58}}$. In contrast there was a highly significant fall of $\dot{\mathrm{V}}_{\mathrm{I}_{\overline{4}}}$ one half hour after fentanyl $(\mathrm{p}<0.01)$, with progressive return towards control at one, two, and four hours; similar changes were observed after morphine. For each drug, changes of $\dot{V}_{I_{70}}$ were substantially

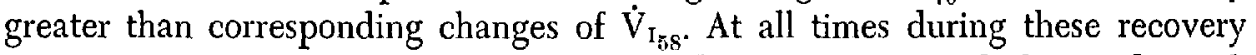
measurements, subjects were conscious and co-operative and, by traditional clinical criteria, were judged to have recovered from the effects of the drugs. Differences between high and low responding subjects were assessed by plotting control measurements against values obtained half and one hour after drugs. No systematic differences were found. These findings suggest that $\Delta \dot{\mathrm{V}}_{\mathrm{I}} / \Delta \mathrm{P}_{\mathrm{CO}_{2}}$ is a sensitive indicator of central nervous activity, but do not support the concepts that individuals with low $\Delta \dot{\mathrm{V}}_{\mathrm{I}} / \Delta \mathrm{P}_{\mathrm{rO}_{2}}$ might be more susceptible to the ventilatory depressant effects of anaesthetic drugs, or that low $\Delta \dot{\mathrm{V}}_{\mathrm{I}} / \Delta \mathrm{P}_{\mathrm{CO}_{2}}$ might be associated with delayed return of spontaneous breathing after general anaesthesia. Plasma thiopentone levels at half, one, and four hours were highly reproducible, in contrast to the wide variation of $\Delta \dot{\mathrm{V}}_{\mathrm{I}} / \Delta \mathrm{P}_{\mathrm{CO}_{2}}$ among subjects in this study. These findings together support the notion that wide variation in clinical recovery from anaesthesia may have a primary physiological basis in addition to variation caused by interindividual differences in drug dosage, biotransformation and excretion.

\section{RÉSUMÉ}

La réponse ventilatoire à l'hypercapnie est reconnue comme un index de mesure précis du contrôle de la respiration; on sait de plus que cette réponse ventilatoire varie grandement d'un individu à l'autre. On sait d'autre part que la récupération de la fonction respiratoire à la suite de l'administration d'un médicament dépresseur, est, elle aussi, fort variable d'un individu à l'autre. En vue de déterminer s'il y avait corrélation entre ces deux phénomènes, on a mesuré la réponse ventilatoire à l'hypercapnie $\left(\Delta \dot{V}_{\mathrm{I}} / \Delta_{\mathrm{CO}_{2}}\right)$ à la suite d'infusion de Thiopentone, de Morphine, de Fentanyl et de soluté salin. Les mesures effectuées sur des volontaires masculins, en bonne santé, ont été faites une demi, une, deux et quatre heures après les injections.

Chacune des trois drogues a réduit de façon très marquée la réponse au $\mathrm{CO}_{2}$ dans la demi-heure qui suivait son injection. La réponse ventilatoire augmentait progressivement pour revenir après quatre heures aux valeurs de départ pour le Thiopentone, mais pour se maintenir en bas de $80 \%$ des valeurs de départ pour la Morphine et le Fentanyl. A partir des équations de régression de chaque réponse ventilatoire, on a calculé la réponse pour des $\mathrm{P}_{\mathrm{CO}_{2}}$ à 58 et $70 \mathrm{~mm} \mathrm{Hg}\left(\dot{\mathrm{V}}_{\mathrm{I}_{\bar{n}} \mathrm{~g}}\right.$ et $\dot{\mathrm{V}}_{\mathrm{I}_{\mathbf{7 0}}}$ ) pour évaluer le déplacement de la courbe de réponse causé par les drogues étudiées. 
Le thiopentone n'amène aucun changement de la $\dot{\mathrm{V}}_{\mathrm{I}_{58}}$, ce qui contraste fortement avec le changement occasionné à une demi-heure par le Fentanyl et la Morphine. Pour chacune de ces drogues, le changement observé à $\dot{V}_{\mathbf{I}_{70}}$ était comparativement plus marqué.

En tout temps, durant ces mesures, les sujets étaient conscients, collaboraient bien et selon les critères cliniques usuels, on pouvait penser qu'ils n'étaient plus sous l'effet du médicament.

En vue d'apprécier l'influence de la réactivité individuelle des sujets, on a rapporté les valeurs de contrôle à celles trouvées une demi-heure et une heure après les injections: aucune différence systématique n'a pu être mise en évidence. Cas données suggèrent que le rapport $\Delta \dot{V}_{1} / \Delta \mathrm{P}_{\mathrm{CO}_{2}}$ est un indicateur sensible de l'activité du système nerveux central, mais elles ne permettent pas d'affirmer que des individus chez qui ce rapport est bas, sont plus susceptibles à la dépression respiratoire par les agents anesthésiques.

Les concentrations plasmatiques du Thiopentone à une demi, une, deux ou quatre heures de linjection, étaient hautement reproduisibles contrairement à la grande dispersion des valeurs du rapport $\Delta \dot{\mathrm{V}}_{\mathrm{I}} / \Delta \mathrm{P}_{\mathrm{CO}_{2}}$ chez nos volontaires.

Ces données permettent de supposer que la récupération clinique de l'anesthésie dépend d'abord de facteurs physiologiques individuels auxquels viendraient s'ajouter des éléments pharmacologiques (dosage, biotransformation, excrétion) eux-mêmes sujets à des variations d'un individu à l'autre. C'est l'addition de ces facteurs physiologiques et pharmacologiques qui expliquerait les grandes différences observées au cours de la récupération de l'anesthésie.

\section{ACKNOWLEDGMENTS}

We thank Dr. A.S. Rebuck and Dr. E.J.M. Campbell for advice and criticism and Mrs. E.M. Inman for expert technical assistance. J.R.A. Rigg was supported by the Canadian Thoracic Society and the Medical Research Council of Canada (MA 5472). Fentanyl was supplied by McNeil Laboratories (Inc.).

\section{REFERENCES}

1. SchaEfEr, K.E. Respiratory pattern and respiratory response to $\mathrm{CO}_{2}$. J. Appl. Physiol. 13: 1 (1958).

2. Rebuck, A.S. \& READ, J. Patterns of ventilatory response to carbon dioxide during recovery from severe asthma. Clin. Sci. 41: 13 (1971).

3. Bellville, J.W. \& SEeD, J.C. The effect of drugs on the respiratory response to carbon dioxide. Anesthesiology 21:727 (1960).

4. DRIPPS, R.D. \& Dumke, P.R. The effect of narcotics on the balance between central and chemoreceptor control of respiration. J. Pharm. \& Expt. Therap. 77: 290 (1943).

5. Severinghaus, J.W. \& Larson, C.P. (JNr.). Handbook of Physiology, Vol. II, Baltimore: Williams \& Wilkins (1965).

6. Munson, E.S., Larson, C.P. Jr., Babad, A.A., Regan, M.J., Buechel, D.R. \& Eger, E.I., II The effects of halothane, fluoroxene and cyclopropane on ventilation: a comparative study in man. Anesthesiology 27: 716 (1966).

7. Larson, C.P., Eger, E.I., II, Muallem, M., Buechel, D.R., Munson, E.S., \& Eisele, J.H. The effects of diethyl ether and methoxyflurane on ventilation: II. A comparative study in man. Anesthesiology 30: 174 (1969). 
8. Lambertsen, C.J. Carbon dioxide and respiration in acid-base homeostasis. Anesthesiology 21: $642(1960)$.

9. READ, D.J.C. A clinical method for assessing the ventilatory response to carbon dioxide. Aust. Ann. Med. 1: 20 (1967).

10. RigG, J.R.A., Rebuck, A.S., \& CAMPBell, E.J.M. The effect of posture on the ventilatory response to $\mathrm{CO}_{2}$. J. Appl. Physiol. 37: 487 (1974).

11. Dayton, P.C., Penel, J.M., Landrau, M.A., Brand, L., \& Mark, L.C. The relationship between binding of thiopental to plasma and its distribution into adipose tissue in man, as measured by a spectrophotofluorometric method. Biochem. Pharmacol. 16: 2321 (1967)

12. LANE, D.J. \& Howels, J.B.L. Relationship between sensitivity to carbon dioxide and clinical features in patients with chronic airways obstruction. Thorax 25: 150 (1970).

13. Plum, F. Reproducibility of the rebreathing carbon dioxide response test using an improved method. Amer, Rev. Resp. Dis, 190: 583 (1974).

14. JENNETt, S. Assessment of respiratory effects of analgesic drugs. Brit. J. Anaesth. 40: 746 (1968).

15. EcKenhoff, J.R. \& Helrich, M. Effect of narcotics, thiopental and nitrous oxide upon respiration and respiratory responses to hypercapnia. Anesthesiology 19: 240 (1958).

16. Совв, S., Converse, J.G., \& Landmessen, C.M. Respiratory responses to carbon dioxide transients during ether and cyclopropane anesthesia. Anesthesiology 19: 359 (1958).

17. BüLow, K. Respiration and wakefulness in man. Acta Physiol. Scand. 59, Suppl. 209 (1963).

18. Clark, F.J. \& von Euler, C. On the regulation of depth and rate of breathing. J. Physiol. (London) 222: 267 (1972).

19. Rebuck, A.S., Rigg, J.R.A., Kangalee, M., \& Pengelly, L.D. Control of tidal volume during rebreathing. J. Appl. Physiol. 37: 473 (1974).

20. Jennett, S., Barker, J., \& Forrest, J.B. A double blind controlled study of the effects on respiration of pentazocine, phenoperidine and morphine in normal man. Brit. J. Anaesth. 40: $864(1968)$.

21. Brazier, M.A.B. The neurophysiological background for anesthesia. Springfield: Charles C. Thomas (1972).

22. Edwards, A.E. \& Bras, J.F. The enchancement of neurological signs under anaesthesia. Brit. J. Anaes. 42: 357 (1970).

23. Cunningham, D.J.C., HeY, E.N., \& Lloyd, B.B. Effect of intravenous infusion of noradrenaline on the respiratory response to carbon dioxide in man. Quart. J. Exptl. Physiol. 43: 394 (1958). 